\title{
MicroRNAs in Endothelial Development and Differentiation
}

\section{Yijiang Zhou ${ }^{1}$, Feng Yang ${ }^{1}$, Yutao Wu ${ }^{1}$, Mei Yang ${ }^{1}$, Qingzhong Xiao ${ }^{2 *}$ and Li Zhang ${ }^{1 *}$}

${ }^{1}$ Department of Cardiology, the First Affiliated Hospital, School of Medicine, Zhejiang University, 79 Qingchun Road, Hangzhou, 310003, Zhejiang, China ${ }^{2}$ Centre for Clinical Pharmacology, William Harvey Research Institute, Barts and the london School of Medicine and Dentistry, Queen Mary University of London, London, EC1M 6BQ, UK

\begin{abstract}
Endothelial integrity or homeostasis is not only essential for regulating arterial activity and vascular tone under physiological conditions, but also critical for triggering various cardiovascular diseases including atherosclerosis and balloon angioplasty if such a balance has been impaired. Moreover, endothelial cell development and differentiation are key steps during embryogenesis and involves co-ordinations of diverse signaling molecules and transcription factors. Therefore, characterizing the molecular mechanisms underlying endothelial differentiation and development will not only improve our understanding of pathogenesis of vascular disease, but also facilitate our ability in generation of vessels cells from pluripotent stem cells for therapeutic purpose. MicroRNAs, a class of small, non-coding RNAs, have been extensively implicated in the regulation of various aspects of biological processes such as embryonic development, tissue/organ homeostasis, and metabolism, as well as almost all the human disease, particularly cancers and cardiovascular diseases. Accumulating evidence has implicated that microRNAs play an important role in regulation of endothelial development, phenotype and function. In this review, we will summarize new findings from recent studies in this field and discuss our current understanding of how microRNAs regulate endothelial development and differentiation from stem cells.
\end{abstract}

Keywords: MicroRNA; Stem cells; Endothelial; Blood vessel; Noncoding RNA

\section{Introduction}

Vascular system forms an extensive network in a living organism to deliver oxygen and nutrients to cells/tissues throughout the body. It is one of the first organ systems to develop and is fundamental for embryonic development and adult life. The Endothelial Cells (ECs) line the internal surface of the entire vascular system and form the barrier between circulating blood and the rest of the vessel wall. Endothelial cells serves to prevent thrombosis and regulate arterial activity through synthesis and release of numerous vasoactive molecules. The endothelium is thus considered as a dynamic and heterogeneous organ with secretory, metabolic, synthetic and immunological functions [1]. Vasculatures are established in two distinct, but close associated processes: vasculogenesis and angiogenesis [2]: initial vasculogenesis generates a primitive network of vessels through de novo formation of endothelial cells from precursor cells called angioblasts. Subsequent angiogenesis then leads to vessel expansion with further EC sprouting and branching. Maturation of the blood vessel involves the recruitment of mural cells to enwrap nascent ECs tubules for stabilization and remodeling. Further specialization of the endothelial cells into arteries, veins, capillaries and lymphatic vessel ensures the proper functioning of the vasculature.

During mammalian embryonic development, the establishment of endothelial cells occurs both extraembryonically and intraembryonically. In the yolk sac, mesodermal precursors of both hematopoietic and endothelial lineage differentiate into a cluster of cells called blood islands, where the inner cells gives rise to hematopoietic cells and the outer cells differentiate into endothelial cells [3]. The subsequent coalescence of blood islands and formation of lumina lead to a primitive vascular plexus. Within the embryo, endothelial precursor cell called angioblasts migrate and differentiate to form the primordial aorta. Simultaneous migration of angioblasts from presomitic cranial mesoderm form endocardial tube in the pericardial area [4]. The commitment of EC lineage from its precursors involves co-operative interaction of many different signaling molecules and transcription factors (for reviews, see Ref $[5,6]$ ). The understanding of molecular mechanism of EC differentiation will greatly benefit regenerative medicine for treating certain vascular disease like atherosclerosis, dissections and aneurysms. Various methods have been descried to generate endothelial cells from pluripotent stem cell, which include Embryonic Stem Cells (ESCs) and induced Pluripotent Stem Cells (iPSCs), but often with limited efficiency [7]. Thus, new techniques and refined protocols are still in need to produce sufficient number of desired cell type for regenerative medicine.

MicroRNAs (miRNAs) are small, non-coding RNAs that play important regulatory roles in various aspects of development, homeostasis and disease by pairing to the mRNAs of protein-coding genes as negative or positive posttranscriptional regulators [8-10]. In mammals, approximately $30 \%$ of protein-coding genes are regulated by microRNAs [11]. miRNA are transcribed into primary miRNAs (primiRNAs), which is first processed in the nucleus into an intermediate form (pre-miRNA) by the microprocessor protein complex composed of an RNase III enzyme Drosha and its cofactor DGCR8. The premiRNAs are then transported via export in 5 into the cytoplasm and further processed by another RNase III enzyme Dicer to form mature

*Corresponding authors: Dr. Li Zhang, Department of Cardiology, the First Affiliated Hospital, School of Medicine, Zhejiang University, 79 Qingchun Road, Hangzhou, 310003, Zhejiang, China. Tel: +86-15925689811; E-mail: li.zhang.uk@gmail.com

Dr. Qingzhong Xiao, Centre for Clinical Pharmacology, William Harvey Research Institute, Barts and the London School of Medicine and Dentistry, Heart Centre, Charterhouse Square, London EC1M 6BQ, United Kingdom. Tel: +44(0)2078826584; E-mail: q.xiao@qmul.ac.uk

Received March 10, 2014; Accepted April 02, 2014; Published April 04, 2014

Citation: Zhou Y, Yang F, Wu Y, Yang M, Xiao Q, et al. (2014) MicroRNAs in Endothelial Development and Differentiation. J Stem Cell Res Ther 4: 191 doi:10.4172/2157-7633.1000191

Copyright: ( $) 2014$ Zhou Y, et al. This is an open-access article distributed under the terms of the Creative Commons Attribution License, which permits unrestricted use, distribution, and reproduction in any medium, provided the original author and source are credited. 
miRNAs. One strand of the mature miRNAs base-pair imperfectly with the 3' Untranlated Region (UTR) of target mRNA by forming an ribonucleoprotein known as the RNA-Induced Silencing Complex (RISC), which contains the Argonaute protein Ago2. RISC complex finally repress mRNA translation and/or induce mRNA degradation, with the latter playing a predominant role [12]. Over the past several years, there has been an increasing amount of evidence suggesting that miRNAs are implicated in regulation of EC development, phenotype and function $[13,14]$. It has been suggested that miRNAs play a divergent role in EC development and differentiation from stem cells: some can maintain stem cells pluripotence, while other promote their differentiation into specific lineages depending on the targets it regulates. In this review, we will discuss the emerging findings to show the functional involvements of microRNAs in regulation of endothelial development and differentiation and signal pathways involved. In particular, we will highlight the individual miRNAs which have been recently identified as the modulators of endothelial differentiation and vasculature development.

\section{Dicer and Endothelial Differentiation and Fucntion}

The global effect of miRNAs on vascular development comes from knock-out studies of the miRNA processing enzyme, Dicer [15]. Zebrafish embryos lacking dicer1 undergo a relative normal morphongeneis during the first week due to maternal Dicer activity, but went into growth arrest and died afterwards [16]. Mutants for both maternal and zygotic dicer (MZdicer) undergo axis formation but display abnormal morphogenesis during gastrulation, brain formation, and heart development associated with lack blood circulation [17]. However, MZ dicer mutants still developed endothelial and hematopoietic precursor cells as their lineage markers $f l i-1$ and $s c l$ were expressed. In mouse, deletion of dicer led to lethality at embryonic day (E)7.5 before formation of primitive streak, due to loss of pluripotent stem cells [15]. Hypomorphic dicer mutants (Dicer ${ }^{\text {ex } 1 / 2}$ ) of mouse embryo also displayed retarded phenotype and died between E12.5 and E14.5 [18]. Formation of blood vessels in embryo and yolk sacs are compromised in dicer ${ }^{\text {ex } 1 / 2}$ mutants, with altered expression of VEGF with its receptor FLT-1 and angiopoiten receptor Tie-1. In consistence with this observation, another line of mouse mutant with hypomorphic dicer1 $\left(\right.$ Dicer $\left.^{\mathrm{d} / \mathrm{d}}\right)$ resulted in female infertility caused by impaired growth of new capillary vessels in the corpus luteum [19].

The generation of two EC-specific Dicer knockout mouse lines, conditional Tie2-Cre; Dicer ${ }^{\text {flox/flox }}$ mice and the tamoxifen-inducible VECad-Cre-ER ${ }^{\mathrm{T} 2}$; Dicer ${ }^{\text {flox/flox }}$ mice, facilitate study on endothelialderived miRNAs in EC differentiation and function [20]. These two mouse lines were hypomorphic for Dicer expression since Dicer levels were reduced but not abolished. As a result, newborn litters were viable and overtly normal. EC-specific Dicer hypomorphs showed significant reduction in angiogenic behavior with exogenous VEGF treatment, and displayed defects in postnatal angiogenesis in response to limb ischemia and wound healing [20]. Dicer silencing in ECs increased the expression of anti-angiogenic factor Thrombospondin-1 (Tsp1), and transfection with components of the miR-17-92 cluster, rescued the defect in EC proliferation and morphogenesis. In Human Microvascular Endothelial Cells (HMECs), the knockdown of Dicer reduced capillary sprouting and tube forming by silencing of critical target miRNAs like lef-7f and mir-27b [21,22]. Also, knocking down of Dicer in ECs altered the expression of several key molecules regulating endothelial functions such as Tie-2/TEK, KDR/VEGFR2, Tie-1, endothelial nitric oxide synthase and interleukin-8 [22]. However, Drosha siRNA-transfected
ECs does not reduce migration or angiogenesis in the in vivo Matrigel plug model [21]. This is probably because of the alternative miRNAprocessing pathway without Drosha-mediated cleavage [23].

\section{miRNA and Endothelial Differentiation}

miRNAs are well-established masters to control the self-renewal and differentiation program of ES cells [24,25]. Dicer or DGCR8deficient ESCs display a significant defective in cell differentiation [2628], which is further supported by the finding that dicer1-knockout mice die at early stages of development [15]. Numerous miRNAs have been shown to promote ESC differentiation into various cell lineages, including cardiomyocytes [29], endothelial cells [30], smooth muscle cells [31], skeletal muscle cells [32], Neuronal Progenitor Cells (NPCs) [33] etc. It has been reported that such cell lineage specifications mediated by miRNAs involves the repressing of the stem cell selfrenewal program by inhibiting core pluripotent factors including homeobox protein Nanog, Sex-Determining Region Y (SRY)-box containing gene 2 (Sox2), Octamer-Binding Protein 4 (Oct4) and Krueppel-like factor 4 (Klf4) [31,34-36], as well as the induction of lineage-specific gene expression program [29,31]. Conversely, ESCspecific cell cycle-regulating miRNAs inhibit ESC differentiation and maintain ESC pluripotency [37]. Introduction of these miRNAs like miR-291-3p, miR-294, and miR-295, together with the core pluripotent factors Oct4, Sox 2 and Klf4, substantially enhanced the efficacy of reprogramming towards iPSCs [38] .

Roles of several miRNAs have been carefully examined in regulating vascular development, angiogenesis and endothelial functions through fine-tuning signaling pathway like VEGF, Notch and Slit/Robo signaling, and those include miR-126 [39,40], miR-221[41], miR-132 [42], miR-218 [43,44], miR-23 27 24 clusters [45], miR-27a/b [46], miR-92 [47], etc.(Refer to Ref [14] for a thorough review). Among them, miR-126 is the most extensively studied for its role in maintaining vessel integrity and directing angiogenesis. Targeted deletion of miR126 in mouse endothelium led to partial embryonic lethality and leaky vessels, due to loss of vascular integrity and defects in endothelial cell proliferation, migration, and angiogenesis [40]. MiR-126 enhance VEGF signaling by inhibiting negative regulators spout-related protein SPRED1 and phosphoinositol-3 kinase regulatory subunit2 (PIK3R2) $[39,40]$. Moreover, miR-126 in zebrafish can be induced by blood flow in the aortic arch, thereby facilitating VEGF-dependent angiogenic remodeling [48]. However, miR-126 does not control endothelial lineage commitment, as evidenced by no increase in CD31-positive endothelial cells or endothelial genes expression with miR-126 overexpression during ES cell differentiation [39]. It rather inhibits hematopoietic differentiation from the common hematopoietic and endothelial progenitors called hemato endothelial cells, and may thus tip the balance to endothelial lineage [49]. This is also supported by the partial but not full embryonic lethality with miR-126 deletion [40]. Thus, although miR-126 are enriched in endothelial cells and Flk-1+ mesodermal endothelial progenitors [50], miR-126 does not specify endothelial lineage, but rather regulates angiogenesis and EC functions like maintaining vessel integrity and controlling vascular inflammation [51].

Though many of the aforementioned miRNAs have been shown to regulate proper EC functions, little is known about their role in EC differentiation. In order to explore the potential roles of miRNAs in endothelial differentiation, researchers used different protocols to induce EC differentiation from ESCs and have identified sets of miRNAs that may share a role $[30,52,53]$. Among them, some are 
Citation: Zhou Y, Yang F, Wu Y, Yang M, Xiao Q, et al. (2014) MicroRNAs in Endothelial Development and Differentiation. J Stem Cell Res Ther 4: 191. doi:10.4172/2157-7633.1000191

Page 3 of 8

associated with angiogenesis (let-7b, 7f, miR-126, 130a, 133a, 133b, 210 , and 296), while others impaired angiogenesis (miR-20a, 20b, 221, and 222) [54]. However, many of them have not been directly tested as whether being able to direct EC differentiation. In this review, we only summarize those microRNAs with a definite role in modulating EC differentiation (Figure 1).

\section{miR-21}

Identified as one of the first mammalian microRNAs, microRNA-21 (miR-21) has been extensively studied and was found to be dysregulated in many pathological conditions including cancer, organ fibrosis and cardiovascular disease [55]. miR-21 is highly expressed in almost all kinds of cancers and therefore considered as an oncomiR. Many of the target genes identified for miR-21 are well-known tumor suppressors, such as Phosphatase and Tensin Homolog (PTEN) [56], Programmed Cell Death 4 (PDCD4) [57], RECK [58], RhoB [59], Bcl-2 [60], sprouty $1 / 2$ [61], Tropomyosin [62], Maspin [63] and so on. Recent studies have also revealed the critical role of miR-21 in mediating diverse pathological process in cardiovascular disease, including cardiac fibrosis [64], myocardial infarction [65,66] and ischemia/reperfusion [67], endothelial-to-Mesenchymal Transition (EndMT) [68], and in advanced peripheral arterial disease [69]. Moreover, miR-21 has been implicated in angiogenic process [70], possibility via regulating endothelial progenitor cell senescence [71] and Angiogenic Progenitor Cells (APCs) dysfunction [72].

The involvement of miR-21 in regulating stem cell self-renewal and differentiation originate from a genetic study on deletion of the neuronal repressor REST (RE1-silencing transcription factor) in ESCs [73]. REST is expressed at high levels in mouse ESCs, with its heterozygous deletion causing loss of self-renewal ability and increased expression of markers specific for multiple lineages. Among many of the REST-suppressed miRNAs, miR-21 was shown to specifically inhibit self-renewal of mouse ES cells, and reduce expression of pluripotent factors Oct4, Nanog, Sox 2 and c-Myc. Later studies showed miR-21 is able to regulate monocyte derived dendritic cell (MDDC) [74] and

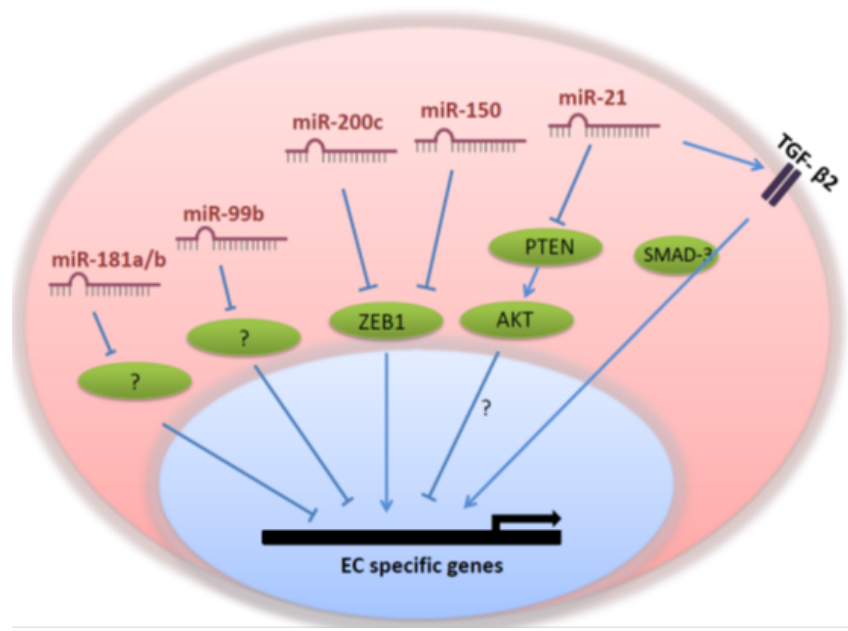

Figure 1: MicroRNA-mediated EC differentiation. Both miR200c and miR-150 promote EC differentiation by transcriptionally de-repressing ZEB1 expression, while miR-21 enhances EC differentiation through inhibition of PTEN/Akt pathway. Moreover, miR-21 also indirectly enhanced TGF- $\beta 2$ production, resulting in EC gene activation in a SMAD3-dependent manner. However, $\mathrm{miR}-181 \mathrm{a} / \mathrm{b}$ and miR-99b mediate EC lineage specification through yet uncharacterized mechanism. granulocytic cell differentiation [75], suggesting its role in repressing stem cell self-renewal and promoting differentiation. This was further confirmed in another report showing miR-21 regulates adipogenic differentiation through the modulation of TGF- $\beta$ signaling in adipose tissue-derived mesenchymal stem cells [76]. Overexpression of miR21 significantly weakened TGF- $\beta$-induced inhibition of adipogenic differentiation through repressed TGFBR2 expression and downstream SMAD3 phosphorylation. Importantly, one recent study on endothelial differentiation from iPSCs also indicated a role of miR-21 in regulation of endothelial differentiation and angiogenesis by modulating TGF- $\beta$ signaling pathway [77]. Overexpression of miR-21 in pre-differentiated iPSCs induced the capillaries formation in vitro and in vivo, and an increase of TGF- $\beta 2$ mRNA and secreted protein. TGF- $\beta 2$, in turn, promotes iPSCs differentiation towards endothelial lineage through SMAD3-dependent pathway. Moreover, miR-21 targets PTEN/Akt pathway during EC differentiation, and PTEN inhibition is required for miR-21 mediated EC differentiation from iPSCs.

\section{miR-200 family}

The miR-200 family consists of five members: miR-200a, miR-200b, miR-200c, miR-141 and miR-429. These five miRNAs are located in two separate chromosomal clusters with the miR-200b-200a-429 cluster at chromosomal location $1 \mathrm{p} 36$ and miR-200c-141 cluster at 12p13. The seed sequences between the two clusters differ in only one nucleotide. By targeting E-box-binding homeobox (ZEB) transcription factors, the miR-200 family negatively regulate Epithelial-to-Mesenchymal Transition (EMT) [78], which is crucial for embyrogenesis and certain pathophysiological conditions like wound healing, organ fibrosis and carcinoma progression [79]. ZEB factors mediate EMT by suppressing epithelial and inducing mesenchymal proteins expression, resulting in breakdown of cell polarity, loss of cell-cell adhesion and acquisition of cell motility. Notably, miR-200 expressions are also transcriptionally repressed by ZEB factors, forming a double-negative feedback loop [80]. This reciprocal loop, depending on the environmental trigger, may switch between the EMT and the reversal process of EMT called Mesenchymal-Epithelial Transition (MET).

It is now known that EMT is associated with stem-cell properties and can increase tumor-initiating capacity of cancer cells [81-83]. Since miR-200 family functions as antagonist to EMT, reduced expression of miR-200 are observed in normal mammary stem cells, breast cancer stem cells (CSC) and embryonic carcinoma cell lines [82]. miR-200 are up-regulated during ESC differentiation [83,84], and overexpression of miR-200 suppress expression of stem cell factors Bmil and Sox 2 in CSCs and mouse ESCs, resulting in stem cell differentiation $[82,83]$. In addition, in neural stem/progenitor cells, miR-200 was required to promote cell-cycle exit and neuronal differentiation through directly targeting Sox2 and the cell cycle regulator E2F3 [85].

It has been suggested that miR-200 regulates cancer stem cell properties through the epigenetic mechanisms $[86,87]$. The conversion of breast cancer cells from a non-stem to a stem-like phenotype is accompanied by the dysregulation of miR-200 family gene expression, with the decreased expression levels of both miR-200 clusters. Interestingly, the miR-200b-200a-429 cluster was silenced through histone modifications mechanism mediated by Polycomb Repressive Complex 2 (PRC2) whereas the repression of miR-200c-141 cluster was regulated by another epigenetic modification-DNA methylation [88]. Inhibition of miR-200 promotes cancer stem cells formation by targeting Suz12 and modulating Suz12 binding, H3-K27 trimethylation and Polycomb-mediated repression of the E-cadherin gene, and [89]. 
However, the action of miR-200 family on normal stem cell selfrenewal or differentiation remains controversial. Maintenance of miR200 expression stalls differentiating ESCs at the Epiblast-Like Stem Cell (EpiSC) stage [90], and overexpression of miR-200c in human ESC inhibited Embryonic Body (EB) formation and repressed the markers for all three blastoderms, partially through targeting transcriptional factor GATA binding protein 4 (GATA4) [91]. miR-200c, together with miR-302s, and miR-369s, can directly reprogram mouse and human somatic cells into iPSCs [92], suggesting a role of these miRNAs in stem cell pluripotency. During OSKM (Oct4, Sox2, Klf4 and c-Myc)induced iPSCs generation, miR-200 mediate BMP-driven epithelialto-mesenchymal transition, which is essential for iPSCs formation at early stage [93]. Furthermore, Oct 4 and Sox 2 can bind to the promoter regions of mir-141/200c and mir-200a/b/429 cluster, respectively, to induce the transcription activation of miR-200 with subsequent suppression of ZEB protein, thus facilitating MET in reprogramming [94].

On the other hand, our recent study has firmly demonstrated that the miR-200c-ZEB feedback loop plays an important role in endothelial differentiation from human ESCs in vitro and in vivo by targeting ZEB1 [30]. Importantly, ZEB1 has been identified as a repressor for EC-specific gene expression in these processes, and miR-200c derepresses such inhibitory effect by inhibiting ZEB1 transcription, and thus promotes endothelial lineage differentiation. Moreover, by using the Matrigel-CD146 ${ }^{+}$EC-committing cells mixture mice implantation model, we observed that blocking ZEB1 signaling could rescue the inhibitory effect of miR-200c inhibition on in vivo vasculogenesis [30]. Finally, in this study we have demonstrated for the first time that miRNA-200c-ZEB1 axis is a critical regulator for chick embryonic blood vessel formation by in vivo inhibition of miRNA-200C or -150 in developing chick embryos. In the meantime, other researchers also reported that miR-200c promotes mesodermal specification while repressing neuroectodermal differentiation from ESCs [95], suggesting that miR-200c may play a cell-autonomous role in mediating EC differentiation from stem cells. Interestingly, miR-200b displays an antiangiogenic activity in tumor and in embryonic vascular development $[96,97]$, partially through repressing the crucial endothelial lineage related transcription factor E26 oncogene homolog 1 (Ets-1) [98]. This may reflect the distinct functions and dynamic regulation of miR200 family members in EC differentiation, behaviors and embryonic vascular development at different stages. Further investigations into explaining such discrepancies and uncovering functional redundancy of different miR-200 family member in EC differentiation, embryonic vascular development and postnatal vasculogenesis/angiogenesis are urgently needed.

\section{miR-150}

miR-150 has been classically implicated in hematopoiesis by regulating cell differentiation in both lymphoid and myeloid lineage [99], and is considered as tumor suppressive gatekeeper in leukemogenesis [100] as demonstrated by its aberrant expression is critical for pathogenesis in a variety of hematopoietic malignancies. However, other studies showed miR-150 secreted via microvesicle from monocytes promoted endothelial cell migration and angiogenic ability $[100,101]$, indicating miR-150 also plays a role in angiogenesis as well as EC differentiation. Such a notion has been nicely demonstrated in our recent study [30]. During EC differentiation from human ESCs, miR-150 expression was significantly increased. Over-expression of miR-150 promotes, while knockdown inhibits EC differentiation from human ESCs in vitro or in vivo. Interestingly, the functional involvement of miR-150 in EC differentiation seems similar to miR$200 c$, in that miR-150 promotes endothelial lineage specification by transcriptionally repressing ZEB1 expression [30]. However, mice deficient in miR-150 are viable, fertile, and morphologically normal [102], indicating the signaling networks by which miR-150 mediates EC differentiation may not be essential for embryonic vasculogenesis, although such discrepancies could be attributed to the compensatory effects of other molecules in the miR-150 knockout mice. Thus further studies to examine the discrepancies existed in the literature and the functional redundancy of different miRNAs or other molecules in EC differentiation and vasculogenesis/angiogenesis would be warranted to fully understand the functional importance of miR-150 in in vivo vasculogenesis or blood vessel formation.

\section{miR-181}

The miR-181 family is composed of six members: miR-181a1/2, miR-181b1/2, miR-181c, and miR-181d. They are expressed in a numbers of tissues like muscle, eye, brain, lung and the hematopoietic compartment [103]. miR-181 family members play critical roles in controlling cardiovascular inflammation by regulating critical signaling pathways such as NF- $\mathrm{KB}$ signaling and molecules relevant to endothelial cell activation $[104,105]$ and immune cell homoeostasis [106-108].

The earliest evidence of miR-181 as a player in stem cell differentiation comes from a study showing miR-181 regulated B-cell development during hematopoietic lineage differentiation [109]. miR-181 also promotes myoblast differentiation through targeting the homeobox protein Hox-A1[110]. In ESCs, miR-181a and miR$181 \mathrm{~b}$ are expressed at low levels, but are sharply induced during differentiation [111]. Through downregulating expression of Cbx7, one of the polycomb repressive complex 1 (PRC1) component, miR181 causes loss of Cbx7/PRC1-mediated repression on lineage-specific genes and guide the embryonic cell toward lineage commitment[111].

In a recent study performing miRNA microarray during defined stages of EC differentiation from human ESCs, miR-181a and -181b were found to increase in a time-dependent manner during EC differentiation and peak in mature hESC-ECs [53]. Overexpression of miR-181a and -181b enhanced the expression levels of EC-specific markers, Pecam1 and VE Cadherin, increased nitric oxide production, and improved hES-EC-induced therapeutic neovascularization in a mouse model of peripheral ischemia. Knockdown of miR-181a and $-181 \mathrm{~b}$ significant reduced vascular endothelial markers at the transcript level and NO production but had no effect on the cell population expressing endothelial marker proteins [53], indicating miR-181a and $-181 b$ may not be essential for directing EC lineage differentiation. It is further corroborated in gene knockout study showing mice deficient for the microRNA clusters miR-181a1b1, miR-181a2b2, and miR181cd (containing Mir181c and Mir181d) do not displayed any obvious gross phenotypic abnormalities in terms of growth, development, or survival [108]. Additionally, miR-181a has been suggested to play an important role in lymphatic endothelial cell specification through targeting Prox1, a homeobox transcription factor which is essential for lymphatic endothelial cell fate [112].

\section{miR-99 family}

The miR-99 family consists of miR-99a, $-99 b$, and -100 . They predominantly act as tumor suppressors by inducing cell cycle arrest [113] and inhibiting cell proliferation [114]. The miR-99 family also 
Citation: Zhou Y, Yang F, Wu Y, Yang M, Xiao Q, et al. (2014) MicroRNAs in Endothelial Development and Differentiation. J Stem Cell Res Ther 4: 191. doi:10.4172/2157-7633.1000191

Page 5 of 8

modulates injury response like post-radiation DNA damage [115] and dermal wound healing [116]. miR-99b was co-identified with miR181 in the abovementioned study of EC differentiation from ESCs [53]. Like miR-181, augmentation of miR-99b induced EC-specific markers expression and nitric oxide generation, but its knockdown did not impact endothelial differentiation, implying that though capable to potentiate EC differentiation from pluripotent ESCs, miR-99 is not indispensible for EC differentiation.

\section{Other miRNAs}

Another set of new miRNAs that may also play a role in endothelial differentiation has been identified by Yoo and coworkers [117-119], but none of them have been functionally characterized. Among them, miR-5739 and miR-6087 modulates the expression of endoglin [117, 118 ], which is glycoprotein receptor of Transforming Growth Factor- $\beta$ (TGF- $\beta$ ) expressed on endothelial cell. Authors reported that miR6078 targets E-cadherin (Cdh) gene [118], while miR-7641 suppressed expression of CXCL1 [119], a member of the CXC chemokine family known to promoting neovascularization, during EC differentiation from ESCs.

\section{Conclusion}

Although extensive efforts have been put into deciphering the molecular mechanism of EC differentiation in the past years, a comprehensive understanding of the exact differentiation program is still far from complete. It has been well established that co-coordinative actions of diverse transcription factors and signaling molecules are required for EC differentiation and vasculature development. Emerging evidence clearly suggests that various miRNAs also play an indispensable in these processes, adding another regulatory layer to EC gene regulation network. Since tissue engineering and stem cell therapy has enormous clinical implications for treating vascular disease like atherosclerosis and artery dissections, a better understanding of EC differentiation program will greatly facilitate the generation of vessels cells from pluripotent stem cells. Particularly, with the maturation of iPS technology, more seed cells are available for constructing biocompatible vessels or intravascular injection of vascular progenitor cells for therapeutic purpose. Importantly, it have been recently reported that fibroblasts can be reprogramed into endothelial cell and smooth muscle cells capable of generating tissue-engineered vessels which can, to some extent, substitute native vessels in vivo [120,121]. miRNAs play a broad role in multiple aspects of endothelial biology, and have been proven to be critical in mediating EC differentiation, as such modulating the expression levels of individual miRNAs in stem cells to generate unlimited functional endothelial cells in vitro will undoubtedly beneficial to cardiovascular regenerative medicine and have huge therapeutic implications in a variety of human diseases.

\section{Acknowledgments}

We are grateful to the supports from British Heart Foundation (FS/09/044/28007, $P G / 11 / 40 / 28891$ and $P G / 13 / 45 / 30326)$. We are also grateful to the supports from National Natural Science Foundation of China Grant (30900571, 81270001 and 81270180 ). This work forms part of the research themes contributing to the translational research portfolio of Barts and the London Cardiovascular Biomedical Research Unit which is supported and funded by the National Institute of Health Research.

\section{References}

1. Fishman AP (1982) Endothelium: a distributed organ of diverse capabilities. Ann N Y Acad Sci 401: 1-8.[PubMed]

2. Potente $M$, Gerhardt $H$, Carmeliet $P(2011)$ Basic and therapeutic aspects of angiogenesis. Cell 146(6): 873-887.[PubMed]
3. De Val S, Black BL (2009) Transcriptional control of endothelial cell development. Dev Cell 16(2): 180-195.[PubMed]

4. Ferguson JE 3rd1, Kelley RW, Patterson C (2005) Mechanisms of endothelial differentiation in embryonic vasculogenesis. Arterioscler Thromb Vasc Biol 25(11): 2246-2254.[PubMed]

5. Park C, Kim TM, Malik AB (2013) Transcriptional regulation of endothelial cell and vascular development. Circ Res 112(10): 1380-1400.[PubMed]

6. Marcelo KL, Goldie LC, Hirschi KK (2013) Regulation of endothelial cell differentiation and specification. Circ Res 112(9): 1272-1287.[PubMed]

7. Fadini GP, Losordo D, Dimmeler S (2012) Critical reevaluation of endothelial progenitor cell phenotypes for therapeutic and diagnostic use. Circ Res 110(4): 624-637.[PubMed]

8. Bartel DP (2009) MicroRNAs: target recognition and regulatory functions. Cell 136(2): 215-233.[PubMed]

9. Sayed D, Abdellatif M (2011) MicroRNAs in development and disease. Physiol Rev 91(3): 827-887.[PubMed]

10. Vasudevan S, Tong Y, Steitz JA (2007) Switching from repression to activation: microRNAs can up-regulate translation. Science 318(5858): 1931-1934. [PubMed]

11. Lewis BP, Burge CB, Bartel DP (2005) Conserved seed pairing, often flanked by adenosines, indicates that thousands of human genes are microRNA targets. Cell 120(1): 15-20.[PubMed]

12. Guo H, Ingolia NT, Weissman JS, Bartel DP (2010) Mammalian microRNAs predominantly act to decrease target mRNA levels. Nature 466(7308): 835840.[PubMed]

13. Suárez Y, Sessa WC (2009) MicroRNAs as novel regulators of angiogenesis. Circ Res 104(4): 442-454.[PubMed]

14. Dang LT, Lawson ND, Fish JE (2013) MicroRNA control of vascular endothelial growth factor signaling output during vascular development. Arterioscler Thromb Vasc Biol 33(2): 193-200.[PubMed]

15. Bernstein E, Kim SY, Carmell MA, Murchison EP, Alcorn H, et al. (2003) Dicer is essential for mouse development. Nat Genet 35(3): 215-217.[PubMed]

16. Wienholds E, Koudijs MJ, van Eeden FJ, Cuppen E, Plasterk RH (2003) The microRNA-producing enzyme Dicer1 is essential for zebrafish development. Nat Genet 35(3): 217-218.[PubMed]

17. Giraldez AJ, Cinalli RM, Glasner ME, Enright AJ, Thomson JM, et al. (2005) MicroRNAs regulate brain morphogenesis in zebrafish. Science 308(5723): 833-838.[PubMed]

18. Yang WJ, Yang DD, Na S, Sandusky GE, Zhang Q, et al. (2005) Dicer is required for embryonic angiogenesis during mouse development. J Biol Chem 280(10): 9330-9335.[PubMed]

19. Otsuka M, Zheng M, Hayashi M, Lee JD, Yoshino O, et al. (2008) Impaired microRNA processing causes corpus luteum insufficiency and infertility in mice. J Clin Invest 118(5): 1944-1954.[PubMed]

20. Suárez $Y$, Fernández-Hernando $C, Y u ~ J$, Gerber SA, Harrison KD, et al (2008) Dicer-dependent endothelial microRNAs are necessary for postnatal angiogenesis. Proc Natl Acad Sci U S A 105(37): 14082-14087.[PubMed]

21. Kuehbacher A, Urbich C, Zeiher AM, Dimmeler S (2007) Role of Dicer and Drosha for endothelial microRNA expression and angiogenesis. Circ Res 101(1): 59-68.[PubMed]

22. Suárez Y, Fernández-Hernando C, Pober JS, Sessa WC (2007) Dicer dependent microRNAs regulate gene expression and functions in human endothelial cells. Circ Res 100(8): 1164-1173.[PubMed]

23. Ruby JG, Jan CH, Bartel DP (2007) Intronic microRNA precursors that bypass Drosha processing. Nature 448(7149): 83-86.[PubMed]

24. Martinez NJ, Gregory RI (2010) MicroRNA gene regulatory pathways in the establishment and maintenance of ESC identity. Cell Stem Cell 7(1): 31-35. [PubMed]

25. Ivey KN, Srivastava D (2010) MicroRNAs as regulators of differentiation and cell fate decisions. Cell Stem Cell 7(1): 36-41.[PubMed]

26. Kanellopoulou C, Muljo SA, Kung AL, Ganesan S, Drapkin R, et al. (2005) Dicer-deficient mouse embryonic stem cells are defective in differentiation and centromeric silencing. Genes Dev 19(4): 489-501.[PubMed] 
Citation: Zhou Y, Yang F, Wu Y, Yang M, Xiao Q, et al. (2014) MicroRNAs in Endothelial Development and Differentiation. J Stem Cell Res Ther 4: 191. doi:10.4172/2157-7633.1000191

Page 6 of 8

27. Murchison EP, Partridge JF, Tam OH, Cheloufi S, Hannon GJ (2005) Characterization of Dicer-deficient murine embryonic stem cells. Proc Nat Acad Sci USA 102(34): 12135-12140.[PubMed]

28. Wang Y, Medvid R, Melton C, Jaenisch R, Blelloch R (2007) DGCR8 is essential for microRNA biogenesis and silencing of embryonic stem cell selfrenewal. Nat Genet 39(3): 380-385.[PubMed]

29. Zhao Y, Samal E, Srivastava D (2005) Serum response factor regulates a muscle-specific microRNA that targets Hand2 during cardiogenesis. Nature 436(7048): 214-220.[PubMed]

30. Luo Z, Wen G, Wang G, Pu X, Ye S, et al. (2013) MicroRNA-200C and -150 play an important role in endothelial cell differentiation and vasculogenesis by targeting transcription repressor ZEB1. Stem Cells 31(9): 1749-1762.[PubMed]

31. Xu N, Papagiannakopoulos T, Pan G, Thomson JA, Kosik KS (2009) MicroRNA-145 regulates OCT4, SOX2, and KLF4 and represses pluripotency in human embryonic stem cells. Cell 137(4): 647-658.[PubMed]

32. Chen JF, Mandel EM, Thomson JM, Wu Q, Callis TE, et al. (2006) The role of microRNA-1 and microRNA-133 in skeletal muscle proliferation and differentiation. Nat Genet 38(2): 228-233.[PubMed]

33. Delaloy C, Liu L, Lee JA, Su H, Shen F, et al. (2010) MicroRNA-9 coordinates proliferation and migration of human embryonic stem cell-derived neural progenitors. Cell Stem Cell 6(4): 323-335.[PubMed]

34. Tay Y, Zhang J, Thomson AM, Lim B, Rigoutsos I (2008) MicroRNAs to Nanog, Oct4 and Sox2 coding regions modulate embryonic stem cell differentiation. Nature 455(7216): 1124-1128.[PubMed]

35. Melton C, Judson RL, Blelloch R (2010) Opposing microRNA families regulate self-renewal in mouse embryonic stem cells. Nature 463(7281): 621-626. [PubMed]

36. Marson A, Levine SS, Cole MF, Frampton GM, Brambrink T, et al. (2008) Connecting microRNA genes to the core transcriptional regulatory circuitry of embryonic stem cells. Cell 134(3): 521-533.[PubMed]

37. Wang Y, Baskerville S, Shenoy A, Babiarz JE, Baehner L, et al. (2008) Embryonic stem cell-specific microRNAs regulate the G1-S transition and promote rapid proliferation. Nat Genet 40(12): 1478-1483.[PubMed]

38. Judson RL, Babiarz JE, Venere M, Blelloch R (2009) Embryonic stem cellspecific microRNAs promote induced pluripotency. Nat Biotechnol 27(5): 459461.[PubMed]

39. Fish JE, Santoro MM, Morton SU, Yu S, Yeh RF, et al. (2008) miR-126 regulates angiogenic signaling and vascular integrity. Dev Cell 15(2): 272-284.[PubMed]

40. Wang S, Aurora AB, Johnson BA, Qi X, McAnally J, et al. (2008) The endothelialspecific microRNA miR-126 governs vascular integrity and angiogenesis. Dev Cell 15(2): 261-271.[PubMed]

41. Nicoli S, Knyphausen CP, Zhu LJ, Lakshmanan A, Lawson ND (2012) miR-221 is required for endothelial tip cell behaviors during vascular development. Dev Cell 22(2): 418-429.[PubMed]

42. Anand S, Majeti BK, Acevedo LM, Murphy EA, Mukthavaram R, et al. (2010) MicroRNA-132-mediated loss of p120RasGAP activates the endothelium to facilitate pathological angiogenesis. Nat Med 16(8): 909-914.[PubMed]

43. Small EM, Sutherland LB, Rajagopalan KN, Wang S, Olson EN (2010) MicroRNA-218 regulates vascular patterning by modulation of Slit-Robo signaling. Circ Res 107(11): 1336-1344.[PubMed]

44. Fish JE, Wythe JD, Xiao T, Bruneau BG, Stainier DY, et al. (2011) A Slit/miR218/Robo regulatory loop is required during heart tube formation in zebrafish. Development 138(7): 1409-1419.[PubMed]

45. Zhou Q, Gallagher R, Ufret-Vincenty R, Li X, Olson EN, et al. (2011) Regulation of angiogenesis and choroidal neovascularization by members of microRNA-23 27 24 clusters. Proc Natl Acad Sci U S A 108(20): 8287-8292. [PubMed]

46. Urbich C, Kaluza D, Frömel T, Knau A, Bennewitz K, et al. (2012) MicroRNA$27 \mathrm{a} / \mathrm{b}$ controls endothelial cell repulsion and angiogenesis by targeting semaphorin 6A. Blood 119(6): 1607-1616.[PubMed]

47. Bonauer A, Carmona G, Iwasaki M, Mione M, Koyanagi M, et al. (2009) MicroRNA-92a controls angiogenesis and functional recovery of ischemic tissues in mice. Science 324(5935): 1710-1713.[PubMed]

48. Nicoli S, Standley C, Walker P, Hurlstone A, Fogarty KE, et al. (2010)
MicroRNA-mediated integration of haemodynamics and Vegf signalling during angiogenesis. Nature 464(7292): 1196-1200.[PubMed]

49. Huang X, Gschweng E, Van Handel B, Cheng D, Mikkola HK, et al. (2011) Regulated expression of microRNAs-126/126* inhibits erythropoiesis from human embryonic stem cells. Blood 117(7): 2157-2165.[PubMed]

50. Ivey KN, Muth A, Arnold J, King FW, Yeh RF, et al. (2008) MicroRNA regulation of cell lineages in mouse and human embryonic stem cells. Cell Stem Cell 2(3) 219-229.[PubMed]

51. Harris TA, Yamakuchi M, Ferlito M, Mendell JT, Lowenstein CJ (2008) MicroRNA-126 regulates endothelial expression of vascular cell adhesion molecule 1. Proc Natl Acad Sci U S A 105(5): 1516-1521.[PubMed]

52. Kane NM, Meloni M, Spencer HL, Craig MA, Strehl R, et al. (2010) Derivation of endothelial cells from human embryonic stem cells by directed differentiation: analysis of microRNA and angiogenesis in vitro and in vivo. Arterioscler Thromb Vasc Biol 30(7): 1389-1397.[PubMed]

53. Kane NM, Howard L, Descamps B, Meloni M, McClure J, et al. (2012) Role of microRNAs 99b, 181a, and 181b in the differentiation of human embryonic stem cells to vascular endothelial cells. Stem Cells 30(4): 643-654.[PubMed]

54. Wu F, Yang Z, Li G (2009) Role of specific microRNAs for endothelial function and angiogenesis. Biochem Biophys Res Commun 386(4): 549-553.[PubMed]

55. Kumarswamy R, Volkmann I, Thum T (2011) Regulation and function of miRNA-21 in health and disease. RNA Biol 8(5): 706-713.[PubMed]

56. Meng F, Henson R, Wehbe-Janek H, Ghoshal K, Jacob ST, et al. (2007) MicroRNA-21 regulates expression of the PTEN tumor suppressor gene in human hepatocellular cancer. Gastroenterology 133(2): 647-658.[PubMed]

57. Frankel LB, Christoffersen NR, Jacobsen A, Lindow M, Krogh A, et al. (2008) Programmed cell death 4 (PDCD4) is an important functional target of the microRNA miR-21 in breast cancer cells. J Biol Chem 283(2): 1026-1033. [PubMed]

58. Gabriely G, Wurdinger T, Kesari S, Esau CC, Burchard J, et al. (2008) MicroRNA 21 promotes glioma invasion by targeting matrix metalloproteinase regulators. Mol Cell Biol 28(17): 5369-5380.[PubMed]

59. Connolly EC, Van Doorslaer K, Rogler LE, Rogler CE (2010) Overexpression of miR-21 promotes an in vitro metastatic phenotype by targeting the tumor suppressor RHOB. Mol Cancer Res 8(5): 691-700.[PubMed]

60. Wickramasinghe NS, Manavalan TT, Dougherty SM, Riggs KA, Li Y, et al. (2009) Estradiol downregulates miR-21 expression and increases miR-21 target gene expression in MCF-7 breast cancer cells. Nucleic Acids Res 37(8): 2584-2595.[PubMed]

61. Hatley ME, Patrick DM, Garcia MR, Richardson JA, Bassel-Duby R, et al (2010) Modulation of K-Ras-dependent lung tumorigenesis by MicroRNA-21. Cancer Cell 18(3): 282-293.[PubMed]

62. Zhu S, Si ML, Wu H, Mo YY (2007) MicroRNA-21 targets the tumor suppressor gene tropomyosin 1 (TPM1). J Biol Chem 282(19): 14328-14336.[PubMed]

63. Zhu S, Wu H, Wu F, Nie D, Sheng S, et al. (2008) MicroRNA-21 targets tumor suppressor genes in invasion and metastasis. Cell Res 18(3): 350-359. [PubMed]

64. Thum T, Gross C, Fiedler J, Fischer T, Kissler S, et al. (2008) MicroRNA-21 contributes to myocardial disease by stimulating MAP kinase signalling in fibroblasts. Nature 456(7224): 980-984.[PubMed]

65. Roy S, Khanna S, Hussain SR, Biswas S, Azad A, et al. (2009) Microrna expression in response to murine myocardial infarction: Mir-21 regulates fibroblast metalloprotease-2 via phosphatase and tensin homologue. Cardiovasc Res 82(1):21-29.[PubMed]

66. Dong S, Cheng Y, Yang J, Li J, Liu X, et al. (2009) MicroRNA expression signature and the role of microRNA-21 in the early phase of acute myocardia infarction. J Biol Chem 284(43): 29514-29525.[PubMed]

67. Cheng Y, Zhu P, Yang J, Liu X, Dong S, et al. (2010) Ischaemic preconditioningregulated miR-21 protects heart against ischaemia/reperfusion injury via antiapoptosis through its target PDCD4. Cardiovasc Res 87(3): 431-439.[PubMed]

68. Kumarswamy R, Volkmann I, Jazbutyte V, Dangwal S, Park DH, et al. (2012) Transforming growth factor- $\beta$-induced endothelial-to-mesenchymal transition is partly mediated by microRNA-21. Arterioscler Thromb Vasc Biol 32(2): 361369.[PubMed] 
Citation: Zhou Y, Yang F, Wu Y, Yang M, Xiao Q, et al. (2014) MicroRNAs in Endothelial Development and Differentiation. J Stem Cell Res Ther 4: 191. doi:10.4172/2157-7633.1000191

Page 7 of 8

69. Wang M, Li W, Chang GQ, Ye CS, Ou JS, et al. (2011) Microrna-21 regulates vascular smooth muscle cell function via targeting tropomyosin 1 in arteriosclerosis obliterans of lower extremities. Arterioscler Thromb Vasc Biol 31(9): 2044-2053.[PubMed]

70. Liu LZ, Li C, Chen Q, Jing Y, Carpenter R, et al. (2011) MiR-21 induced angiogenesis through AKT and ERK activation and HIF-1 $\alpha$ expression. PLoS One 6(4): e19139.[PubMed]

71. Zhu S, Deng S, Ma Q, Zhang T, Jia C, et al. (2013) MicroRNA-10A* and MicroRNA-21 modulate endothelial progenitor cell senescence via suppressing high-mobility group A2. Circ Res 112(1): 152-164.[PubMed]

72. Fleissner F, Jazbutyte V, Fiedler J, Gupta SK, Yin X, et al. (2010) Shor communication: Asymmetric dimethylarginine impairs angiogenic progenitor cell function in patients with coronary artery disease through a microrna-21 dependent mechanism. Circ Res 107(1): 138-143.[PubMed]

73. Singh SK, Kagalwala MN, Parker-Thornburg J, Adams H, Majumder S (2008) REST maintains self-renewal and pluripotency of embryonic stem cells. Nature 453(7192): 223-227.[PubMed]

74. Hashimi ST, Fulcher JA, Chang MH, Gov L, Wang S, et al. (2009) MicroRNA profiling identifies miR-34a and miR-21 and their target genes JAG1 and WNT1 in the coordinate regulation of dendritic cell differentiation. Blood 114(2): 404414.[PubMed]

75. Velu CS, Baktula AM, Grimes HL (2009) Gfi1 regulates miR-21 and miR-196b to control myelopoiesis. Blood 113(19): 4720-4728.[PubMed]

76. Kim YJ, Hwang SJ, Bae YC, Jung JS (2009) MiR-21 regulates adipogenic differentiation through the modulation of TGF-beta signaling in mesenchymal stem cells derived from human adipose tissue. Stem Cells 27(12): 3093-3102. [PubMed]

77. Di Bernardini E, Campagnolo P, Margariti A, Zampetaki A, Karamariti E, et al (2014) Endothelial lineage differentiation from induced pluripotent stem cells is regulated by microRNA-21 and transforming growth factor $\beta 2$ (TGF- $\beta 2$ ) pathways. J Biol Chem 289(6): 3383-3393.[PubMed]

78. Park SM, Gaur AB, Lengyel E, Peter ME (2008) The miR-200 family determines the epithelial phenotype of cancer cells by targeting the E-cadherin repressors ZEB1 and ZEB2. Genes Dev 22(7): 894-907.[PubMed]

79. Thiery JP, Acloque H, Huang RY, Nieto MA (2009) Epithelial-mesenchymal transitions in development and disease. Cell 139(5): 871-890.[PubMed]

80. Burk U, Schubert J, Wellner U, Schmalhofer O, Vincan E, et al. (2008) A reciprocal repression between ZEB1 and members of the miR-200 family promotes EMT and invasion in cancer cells. EMBO Rep 9(6): 582-589. [PubMed]

81. Mani SA, Guo W, Liao MJ, Eaton EN, Ayyanan A, et al. (2008) The epithelialmesenchymal transition generates cells with properties of stem cells. Cell 133(4): 704-715.[PubMed]

82. Shimono Y, Zabala M, Cho RW, Lobo N, Dalerba P, et al. (2009) Downregulation of miRNA-200c links breast cancer stem cells with normal stem cells. Cell 138(3): 592-603.[PubMed]

83. Wellner U, Schubert J, Burk UC, Schmalhofer O, Zhu F, et al. (2009) The EMTactivator ZEB1 promotes tumorigenicity by repressing stemness-inhibiting microRNAs. Nat Cell Biol 11(12): 1487-1495.[PubMed]

84. Bar M, Wyman SK, Fritz BR, Qi J, Garg KS, et al. (2008) MicroRNA discovery and profiling in human embryonic stem cells by deep sequencing of small RNA libraries. Stem Cells 26(10): 2496-2505.[PubMed]

85. Peng C, Li N, Ng YK, Zhang J, Meier F, et al. (2012) A unilateral negative feedback loop between miR-200 microRNAs and Sox2/E2F3 controls neural progenitor cell-cycle exit and differentiation. J Neurosci 32(38): 13292-13308. [PubMed]

86. Tellez CS, Juri DE, Do K, Bernauer AM, Thomas CL, et al. (2011) Emt and stem cell-like properties associated with mir-205 and mir-200 epigenetic silencing are early manifestations during carcinogen-induced transformation of human lung epithelial cells. Cancer Res 71(8): 3087-3097.[PubMed]

87. Davalos V, Moutinho C, Villanueva A, Boque R, Silva P, et al. (2012) Dynamic epigenetic regulation of the microRNA-200 family mediates epithelial and mesenchymal transitions in human tumorigenesis. Oncogene 31(16): 2062 2074.[PubMed]

88. Lim YY, Wright JA, Attema JL, Gregory PA, Bert AG, et al. (2013) Epigenetic modulation of the miR-200 family is associated with transition to a breast cancer stem-cell-like state. J Cell Sci 126(pt 10): 2256-2266.[PubMed]

89. Iliopoulos D, Lindahl-Allen M, Polytarchou C, Hirsch HA, Tsichlis PN, et al (2010) Loss of miR-200 inhibition of Suz12 leads to polycomb-mediated repression required for the formation and maintenance of cancer stem cells. Mol Cell 39(5): 761-772.[PubMed]

90. Gill JG, Langer EM, Lindsley RC, Cai M, Murphy TL, et al. (2011) Snail and the microRNA-200 family act in opposition to regulate epithelial-to-mesenchymal transition and germ layer fate restriction in differentiating ESCs. Stem Cells 29(5): 764-776.[PubMed]

91. Huang HN, Chen SY2, Hwang SM3, Yu CC2, Su MW4, et al. (2014) miR-200c and GATA binding protein 4 regulate human embryonic stem cell renewal and differentiation. Stem Cell Res 12(2): 338-353.[PubMed]

92. Miyoshi N, Ishii H, Nagano H, Haraguchi N, Dewi DL, et al. (2011) Reprogramming of mouse and human cells to pluripotency using mature microRNAs. Cell Stem Cell 8(6): 633-638.[PubMed]

93. Samavarchi-Tehrani P, Golipour A, David L, Sung HK, Beyer TA, et al. (2010) Functional genomics reveals a BMP-driven mesenchymal-to-epithelial transition in the initiation of somatic cell reprogramming. Cell Stem Cell 7(1) 64-77.[PubMed]

94. Wang G, Guo X, Hong W, Liu Q, Wei T, et al. (2013) Critical regulation of miR200/ZEB2 pathway in Oct4/Sox2-induced mesenchymal-to-epithelial transition and induced pluripotent stem cell generation. Proc Natl Acad Sci U S A 110(8) 2858-2863.[PubMed]

95. Du ZW, Ma LX, Phillips C, Zhang SC (2013) miR-200 and miR-96 families repress neural induction from human embryonic stem cells. Development 140(12): 2611-2618.[PubMed]

96. Chang SH, Lu YC, Li X, Hsieh WY, Xiong Y, et al. (2013) Antagonistic function of the rna-binding protein hur and mir-200b in post-transcriptional regulation of vascular endothelial growth factor-a expression and angiogenesis. J Biol Chem 288(7): 4908-4921.[PubMed]

97. Kim Y, Park D, Kim H, Choi M, Lee H, et al. (2013) miR-200b and cancer/testis antigen CAGE form a feedback loop to regulate the invasion and tumorigenic and angiogenic responses of a cancer cell line to microtubule-targeting drugs. J Biol Chem 288(51): 36502-36518.[PubMed]

98. Chan YC, Khanna S, Roy S, Sen CK (2011) miR-200b targets Ets-1 and is down-regulated by hypoxia to induce angiogenic response of endothelial cells. J Biol Chem 286(3): 2047-2056.[PubMed]

99. He Y, Jiang $X$, Chen $\mathrm{J}$ (2013) The role of miR-150 in normal and malignant hematopoiesis. Oncogene.[PubMed]

100. Jiang X, Huang H, Li Z, Li Y, Wang X, et al. (2012) Blockade of miR-150 maturation by MLL-fusion/MYC/LIN-28 is required for MLL-associated leukemia. Cancer Cell 22(4): 524-535.[PubMed]

101.Zhang Y, Liu D, Chen X, Li J, Li L, et al. (2010) Secreted monocytic miR150 enhances targeted endothelial cell migration. Mol Cell 39(1): 133-144. [PubMed]

102.Xiao C, Calado DP, Galler G, Thai TH, Patterson HC, et al. (2007) MiR-150 controls $\mathrm{B}$ cell differentiation by targeting the transcription factor c-Myb. Cell 131(1): 146-159.[PubMed]

103. Sun X, Sit A1, Feinberg MW2 (2014) Role of miR-181 family in regulating vascular inflammation and immunity. Trends Cardiovasc Med 24(3): 105-112. [PubMed]

104. Sun X, Icli B, Wara AK, Belkin N, He S, et al. (2012) MicroRNA-181b regulates NF-kB-mediated vascular inflammation. J Clin Invest 122(6): 1973-1990. [PubMed]

105. Sun X, He S, Wara AK, Icli B, Shvartz E, et al. (2014) Systemic delivery of microRNA-181b inhibits nuclear factor-kB activation, vascular inflammation, and atherosclerosis in apolipoprotein E-deficient mice. Circ Res 114(1): 32 40.[PubMed]

106. Li QJ, Chau J, Ebert PJ, Sylvester G, Min H, et al. (2007) miR-181a is an intrinsic modulator of $T$ cell sensitivity and selection. Cell 129(1): 147-161. [PubMed]

107. Li G, Yu M, Lee WW, Tsang M, Krishnan E, et al. (2012) Decline in miR-181a expression with age impairs $T$ cell receptor sensitivity by increasing DUSP6 activity. Nat Med 18(10): 1518-1524.[PubMed] 
Citation: Zhou Y, Yang F, Wu Y, Yang M, Xiao Q, et al. (2014) MicroRNAs in Endothelial Development and Differentiation. J Stem Cell Res Ther 4: 191. doi:10.4172/2157-7633.1000191

Page 8 of 8

108. Henao-Mejia J, Williams A, Goff LA, Staron M, Licona-Limón P, et al. (2013) The microRNA miR-181 is a critical cellular metabolic rheostat essential for NKT cell ontogenesis and lymphocyte development and homeostasis. Immunity 38(5): 984-997.[PubMed]

109. Chen CZ, Li L, Lodish HF, Bartel DP (2004) MicroRNAs modulate hematopoietic lineage differentiation. Science 303(5654): 83-86.[PubMed]

110. Naguibneva I, Ameyar-Zazoua M, Polesskaya A, Ait-Si-Ali S, Groisman R, et al. (2006) The microRNA miR-181 targets the homeobox protein Hox-A11 during mammalian myoblast differentiation. Nat Cell Biol 8(3): 278-284. [PubMed]

111. O’Loghlen A, Muñoz-Cabello AM, Gaspar-Maia A, Wu HA, Banito A, et al. (2012) MicroRNA regulation of Cbx7 mediates a switch of Polycomb orthologs during ESC differentiation. Cell Stem Cell 10(1): 33-46.[PubMed]

112. Kazenwadel J, Michael MZ, Harvey NL (2010) Prox1 expression is negatively regulated by miR-181 in endothelial cells. Blood 116(13): 2395-2401.[PubMed]

113. Li D, Liu X, Lin L, Hou J, Li N, et al. (2011) MicroRNA-99a inhibits hepatocellular carcinoma growth and correlates with prognosis of patients with hepatocellular carcinoma. J Biol Chem 286(42): 36677-36685.[PubMed]

114. Sun D, Lee YS, Malhotra A, Kim HK, Matecic M, et al. (2011) miR-99 family of MicroRNAs suppresses the expression of prostate-specific antigen and prostate cancer cell proliferation. Cancer Res 71(4): 1313-1324.[PubMed]

115. Mueller AC, Sun D, Dutta A (2013) The miR-99 family regulates the DNA damage response through its target SNF2H. Oncogene 32(9): 1164-1172. [PubMed]

116. Jin Y, Tymen SD, Chen D, Fang ZJ, Zhao Y, et al. (2013) MicroRNA-99 family targets AKT/mTOR signaling pathway in dermal wound healing. PLoS One 8(5): e64434.[PubMed]

117. Yoo JK, Kim J, Choi SJ, Kim CH, Lee DR, et al. (2011) The hsa-miR-5739 modulates the endoglin network in endothelial cells derived from human embryonic stem cells. Biochem Biophys Res Commun 415(2): 258-262. [PubMed]

118. Yoo JK, Kim J, Choi SJ, Noh HM, Kwon YD, et al. (2012) Discovery and characterization of novel microRNAs during endothelial differentiation of human embryonic stem cells. Stem Cells Dev 21(11): 2049-2057.[PubMed]

119. Yoo JK, Jung HY, Kim CH, Son WS, Kim JK (2013) miR-7641 modulates the expression of CXCL1 during endothelial differentiation derived from human embryonic stem cells. Arch Pharm Res 36(3): 353-358.[PubMed]

120. Margariti A, Winkler B, Karamariti E, Zampetaki A, Tsai TN, et al. (2012) Direc reprogramming of fibroblasts into endothelial cells capable of angiogenesis and reendothelialization in tissue-engineered vessels. Proc Natl Acad Sci U S A 109(34): 13793-13798.[PubMed]

121. Karamariti E, Margariti A, Winkler B, Wang X, Hong X, et al. (2013) Smooth muscle cells differentiated from reprogrammed embryonic lung fibroblasts through DKK3 signaling are potent for tissue engineering of vascular grafts. Circ Res 112(11): 1433-1443.[PubMed] 